\title{
FLEXURAL TESTING OF WOOD-CONCRETE COMPOSITE BEAM MADE FROM KAMPER AND BANGKIRAI WOOD
}

\author{
Fengky Satria Yoresta \\ Department of Forest Product, Faculty of Forestry \\ Bogor Agricultural University, Bogor \\ syfengky@gmail.com
}

\begin{abstract}
Certain wood has a tensile strength that almost equal with steel rebar in reinforced concrete beams. This research aims to understand the capacity and flexural behavior of concrete beams reinforced by wood (wood-concrete composite beam). Two different types of beams based on placement positions of wood layers are proposed in this study. Two kinds of wood used are consisted of Bangkirai (Shorea laevifolia) and Kamper (Cinnamomum camphora), meanwhile the concrete mix ratio for all beams is 1 cement : 2 fine aggregates : 3 coarse aggregates. Bending test is conducted by using one-point loading method. The results show that composite beam using Bangkirai wood is stronger than beams using Kamper wood. More thicker wood layer in tensile area will increase the flexural strength of beams. Crack patterns identified could be classified into flexural cracks, shear cracks, and split on wood layer.
\end{abstract}

Keywords: beam, behavior, komposite, concrete, flexural, wood

\begin{abstract}
Abstrak
Beberapa jenis kayu tertentu memiliki kekuatan tarik yang hampir sama dengan tulangan baja pada balok beton bertulang. Penelitian ini bertujuan memahami kapasitas dan perilaku lentur balok beton bertulang yang diperkuat menggunakan kayu (balok komposit beton-kayu). Dua tipe balok yang berbeda berdasarkan posisi penempatan kayu digunakan dalam penelitian ini. Dua jenis kayu yang digunakan adalah kayu Bangkirai (Shorea laevifolia) and Kamper (Cinnamomum camphora), sementara itu rasio campuran beton untuk semua balok menggunakan perbandingan 1 semen : 2 agregat halus : 3 agregat kasar. Pengujian lentur dilakukan menggunakan metode onepoint loading. Hasil penelitian menunjukkan bahwa balok komposit dengan kayu Bangkirai lebih kuat dibandingkan balok dengan kayu Kamper. Semakin tebal lapisan kayu yang berada di daerah tarik akan meningkatkan kekuatan lentur balok. Pola kerusakan yang teridentifikasi dapat diklasifikasikan menjadi retak lentur, retak geser, dan pecah pada kayu.
\end{abstract}

Kata Kunci: balok, perilaku, komposit, beton, lentur, kayu

\section{Introduction}

Concrete is a brittle material which has a much lower tensile strength than its compressive strength. In its application as structural components, concrete is combined with steel reinforcement to make it more able to withstand the tensile. However, the use of steel as concrete reinforcement for many houses in rural communities tend to be wasteful in terms of cost. Its price makes these materials need to be replaced with other alternatives materials.

Wood can be considered as an alternative to steel reinforcement for community residential houses. Wood is a naturally occurring compisite material (Gangarao et al. 2007) that has a high enough in stiffness and tensile strength parallel grain (Thelandersson 2003). The use of wood can 
also help in contribution to the problem of global warming (Pranata et al. 2012). Table 1 shows strength/density ratio for several structural materials.

Wood-concrete composite beam is an innovation that combines the use of concrete and wood as structural elements. Composite materials are man-made or natural materials that consist of at least two different constituent materials, the resulting composite material being different from the constituent materials (Gangarao et al. 2007). The behavior of composite beams that occurs as a result of a merger between concrete and wood is expected to match the strength and stiffness of beams using concrete and steel reinforcement.

Unlike with ordinary reinforced concrete beams, which is the position of reinforcing steel inside the beams, wood materials in wood-concrete composite beam can be placed inside and/or outside of the concrete. In order to connect between wood and concrete, it is used connectors that is very important to resist shear force happened between two of theses materials. It is intended that the beam keep behaves as a single material (composite).

Table 1. strength/density ratio of some structural materials

\begin{tabular}{lc}
\hline \multicolumn{1}{c}{ Material } & Strength/Density $10^{-3} \mathrm{MPa}^{3} \mathrm{~m} / \mathrm{kg}$ \\
\hline Structural steel & $50-130$ \\
Aluminium & $40-110$ \\
Concrete, compression & $13-50$ \\
Clear softwood, tension & $100-300$ \\
Clear softwood, compression & $70-150$ \\
& \\
Structural timber, tension & $30-80$ \\
Glass fibre in epoxi, typical value, tension & 500 \\
Carbon fibre in epoxi, typical value, tension & 1000 \\
\hline
\end{tabular}

Source: Thelandersson, 2003

This research aims to understand the capacity and flexural behavior of wood-concrete composite beams. Research on wood-concrete composite beams have not many performed. Therefore, this research is very necessary in order to increase the scientific information related to the use of wood as a construction materials.

\section{Materials and Methods Materials Properties}

Two kinds of wood used in this study as a constituent of the composite material are Bangkirai (Shorea laevifolia) and Kamper (Cinnamomum camphora). These woods are classified as class 1 due to strength with an average value of modulus of elasticity (MOE) of $100.000 \mathrm{~kg} . \mathrm{cm}^{-2}$ or $1422,33 \mathrm{ksi}$ based on Indonesian Timber Construction Code (PKKI 1961).

The mixing ratio of concrete is 1 cement : 2 fine aggregates : 3 coarse aggregates, which has a minimum compresive strength of $150 \mathrm{~kg} / \mathrm{cm}^{2}$ (Boen 2010). The flexural testing on beam is conducted when the concrete has reached a minimum 28 days of age to ensure the compressive strength of concrete are perfectly achieved.

\section{Geometry}

Wood-concrete composite beams tested has a total length of $115 \mathrm{~cm}$ with $100 \mathrm{~cm}$ long for span. Overall dimensions of cross section of the beam is $5 \times 10 \mathrm{~cm}^{2}$, which consists of a $8.5 \mathrm{~cm}$ thick layer of concrete and two layers of wood with a thickness of $0.5 \mathrm{~cm}$ and $1 \mathrm{~cm}$ respectively. The layer of wood is placed at the top and bottom side of beam as shown in Figure 1. 
The beams were divided into 2 types $\left(\mathrm{CB}_{1}\right.$ and $\left.\mathrm{CB}_{2}\right)$ based on differences in position of wood layers plus control beam (CB) which is only made of concrete without any layers of wood (Table 2). Each type of beam amounted to 10 specimens. Beam type $1\left(\mathrm{CB}_{1}\right)$ has $1 \mathrm{~cm}$ thickness of wood layer on top side of beam (compressive area) and $0.5 \mathrm{~cm}$ at the bottom side (tensile area). In contrast to beam type $2\left(\mathrm{CB}_{2}\right), 1 \mathrm{~cm}$ layer of wood is exist at the bottom side (tensile area) and $0.5 \mathrm{~cm}$ on top side of beam (compressive area). Figure 2 shows the two types of beam section.

A total of 14 pieces of nails with $5 \mathrm{~cm}$ in length and $0.31 \mathrm{~cm}$ in diameter is used to connect each layer of wood to the concrete. Nails are placed at a distance of $15 \mathrm{~cm}$ along span of beam to ensure concrete and wood are well connected. Nails are arranged so its position on top wood is between two other nails on bottom wood. Figure 3 shows the details of nails position that connect between wood and concrete.

\section{Test Set-up}

All specimens were tested as a simple beam with one load at the middle of span (one-point loading). The test is conducted using 5 tons capacity of Instron UTM (Figure 5). Beams were then investigated by measuring cracks that occur after bending tests performed. Figure 4 shows the specimens under construction.

Table 2. Flexural Beam specimen summary

\begin{tabular}{lll}
\hline Specimen & Wood used & Type of beam \\
\hline $\mathrm{C}$ & - & Control beam \\
\hline AK1 & Bangkirai & $\mathrm{CB}_{1}$ \\
\hline AK2 & Kamper & $\mathrm{CB}_{2}$ \\
\hline BK1 & Bangkirai & \\
\hline BK2 & Kamper &
\end{tabular}

Source: Research Documentation

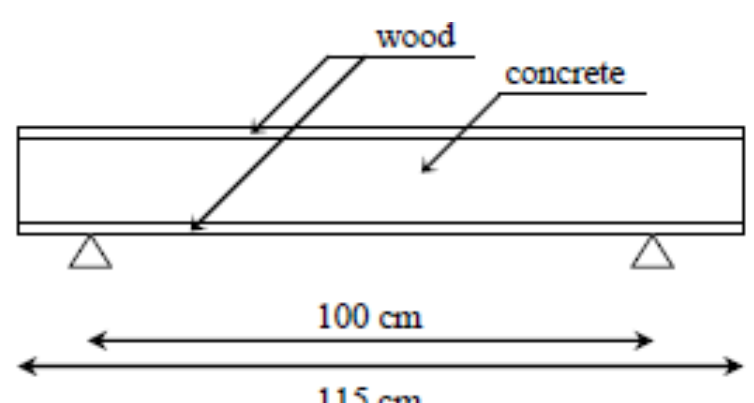

$115 \mathrm{~cm}$

Figure 1. Specimen configuration Source: Research Documentation

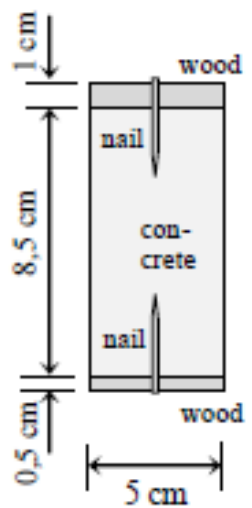

(a)

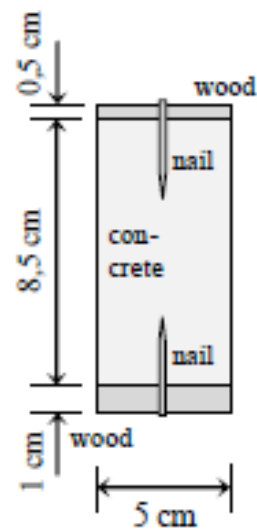

(b)
Figure 2. Cross section of beams: (a) $\mathrm{CB}_{1}$, (b) $\mathrm{CB}_{2}$ Source: Research Documentation 

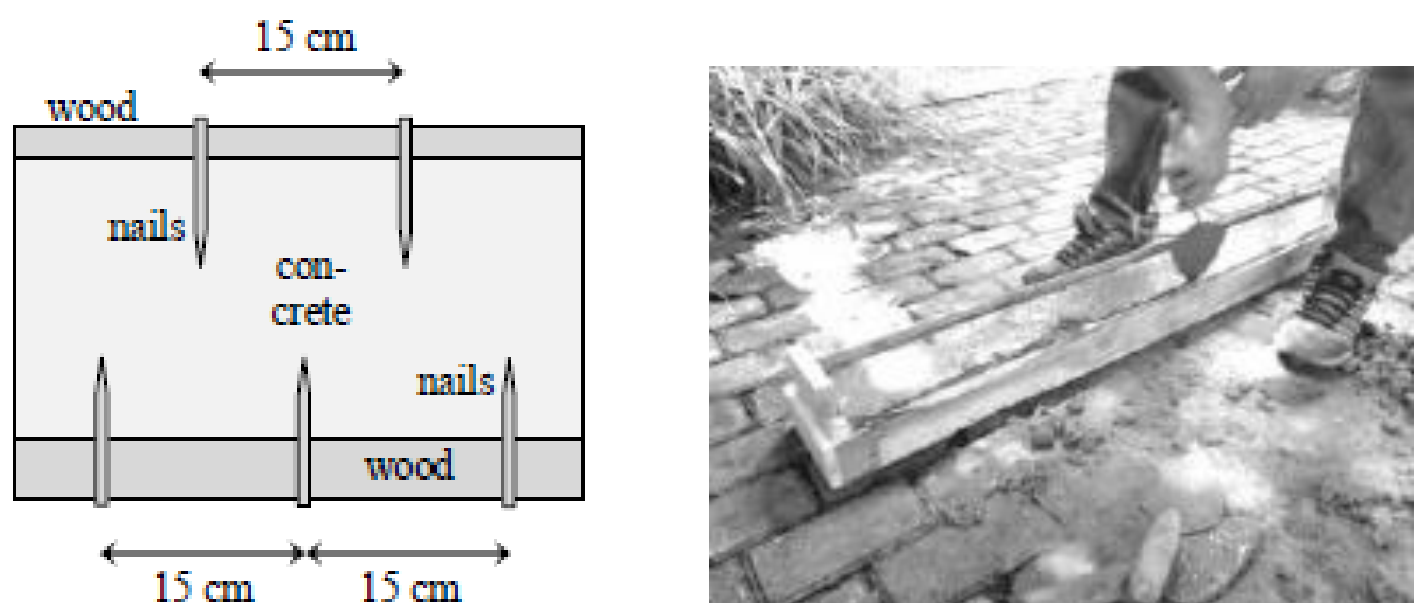

Figure 3. Nails position in detail (side view) Source: Research Documentation

Figure 4. Specimen under construction Source: Research Documentation

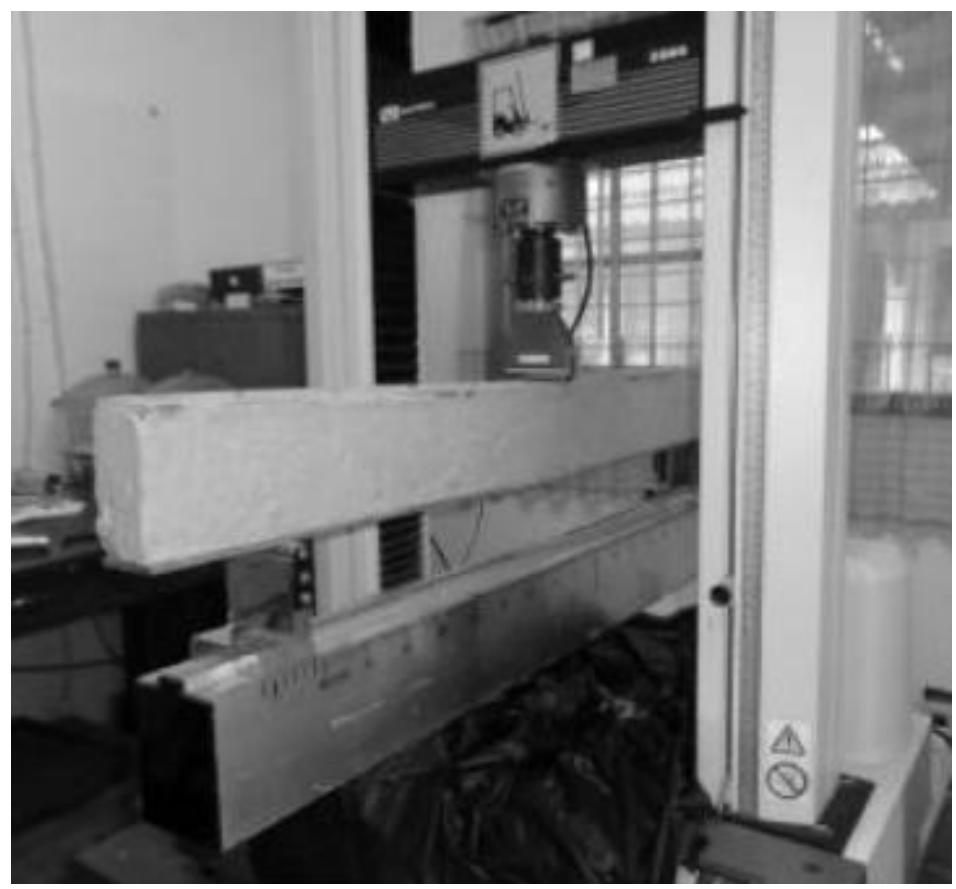

Figure 5. Test Set-up

Source: Research Documentation

\section{Results and Discussion}

Test Results

Table 3 shows the flexural testing results of wood-concrete composite beam at ultimate condition which consists of the ultimate failure load $\left(\mathrm{P}_{\text {meas }}\right)$, crack width, and maximum crack position that occurs in all beam specimens. Ultlimate condition referred means a maximum condition of beam behavior in overall. In this condition, beam is not completely behaving as composite because occurred after concrete having frst crack (fully composite condition). Layers of wood and concrete in this condition together withstand the shear force only, while bending moment 
is detained by two layers of wood. Table 4 shows the average of moment resistance capacity of beams and average deflection at fully composite condition (first crack) and ultimate condition.

Figure 7 shows the crack patterns for all of the beam specimens. Figure $7 \mathrm{a}$ to $7 \mathrm{f}$ show the condition of crack pattern that occurs on beam specimen type $\mathrm{CB}_{1}$, while Figure $7 \mathrm{~g}$ to 71 show the cracks pattern of beam specimen type $\mathrm{CB}_{2}$. The flexural crack patterns of specimens $A K 1$ and $A K 2$ are shown in Figure 7a and 7d, whereas for specimens BK1 dan BK2 are shown in Figure 7g and 7j. Figure $7 \mathrm{~b}$ and $7 \mathrm{e}$ show the shear failure that occurs between the wood layers and concrete on specimen AK1 and AK2, while for specimen BK1 dan BK2 are shown in Figure 7h and 7k. In addition to cracking in concrete components, beams also suffered damage on wood layers. Wood layers damages for all specimens (AK1, AK2, BK1, dan BK2) are shown in Figure 7c, 7f, 7i, and 71 respectively.

\section{Discussion of Results}

All beams failure start from crack on concrete in tensile area. Concrete on all beams have flexural cracks which tend to perpendicular to the horizontal axis of beam. Flexural cracks in the concrete starting from nails position at the tensile area which further spread to the top (compresive area).The composite behavior of all beams is just happened until concrete having first crack at the tensile area. This crack end together load bearing behavior between concrete and wood layers. The load is then detained only by shear connectors (nails) and wood layers until ultimate achieved and then collapse. The shear connectors will withstand shear forces while wood layers will resist bending moment.After flexural cracks in concrete, shear forces that occur between concrete and wood layers becomes larger. Shear failure is only found at the interface between layers of wood and concrete, particularly on beam using Bangkirai wood. The damage is only found at the tensile area of the beam. Shear failure occured in beams which are using Bangkirai wood as reinforcements has led to nails that connect layers of wood and concrete to be changed in angel up to $30^{\circ}$ from its vertical position. Moreover, split crack on wood layers is occured at around restraint area and only found on beam using Bangkirai wood (Table 3). Figure 6 shows a typical load-deflection curve of proposed wood-concrete composite beams.

The composite beams with Kamper wood is more able to withstand shear forces than the beams with Bangkirai wood. Up to failure, the composite beam with Kamper wood (AK2 and BK2) just suffer flexural cracks (Table 3) and almost no shear failure. The layers of wood just make a distance of not more than $1 \mathrm{~mm}$ to the concrete and there are no any change in position identified of wood layers to the concrete in horizontal direction. Nails posistion are still on $90^{\circ}$ to the direction of wood fibers even though there has been a total collapse of the beam. The composite beams using Kamper wood do not suffer a split on wood layers.

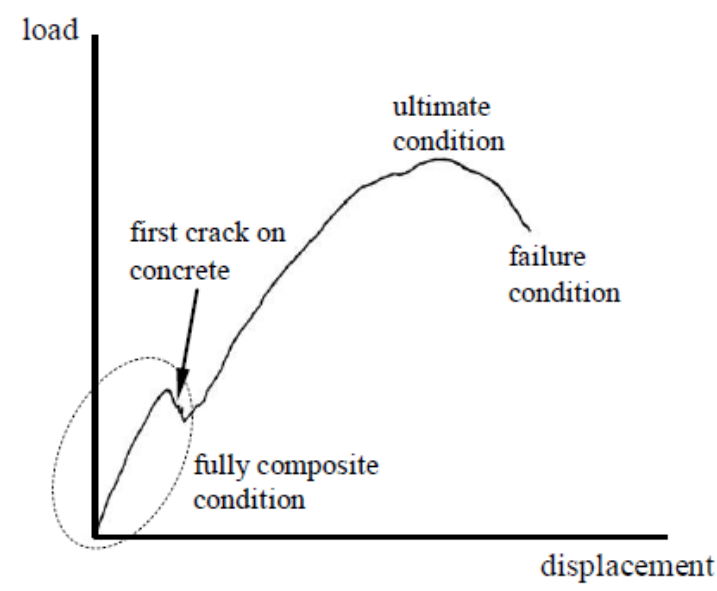

Figure 6. Tipical load-deflection curve of present study of wood-concrete composite beam Source: Research Documentation 
Beams AK1 and BK1 have same type of collapse namely flexure, shear tension, and split on wood. On the other hand, beam AK2 and BK2 are also suffering the same type of collapse (Table 3), namely flexural cracks. This indicates that Kamper wood is strong enough to hold nails which have the function to withstand shear force between wood layers and concrete due to external loads. On the contrary, split that occurred on beam AK1 and BK1 is strongly suspected caused by a lack resistant of nails to resist shear forces.

Table 3. Test Result in Ultimate Condition

\begin{tabular}{|c|c|c|c|c|c|}
\hline $\begin{array}{l}\text { Beam } \\
\text { specimen }\end{array}$ & $\begin{array}{l}\text { Material } \\
\text { strengthen }\end{array}$ & $\begin{array}{l}\mathrm{P}_{\text {meas }} \\
(\mathrm{kN})\end{array}$ & $\begin{array}{l}\text { Maximum } \\
\text { crack width } \\
(\mathrm{mm})\end{array}$ & $\begin{array}{l}\text { Maximum } \\
\text { crack position } \\
(\mathrm{mm})\end{array}$ & Failure mode \\
\hline $\mathrm{C}$ & Control beam & & & & Flexure \\
\hline AK1 & Bangkirai & 3.18 & 230 & 910 & $\begin{array}{l}\text { Flexure, shear tension, } \\
\text { split on wood }\end{array}$ \\
\hline AK2 & Kamper & 2.83 & 410 & 110 & Flexure \\
\hline BK1 & Bangkirai & 4.77 & 420 & 1150 & $\begin{array}{l}\text { Flexure, shear tension, } \\
\text { split on wood }\end{array}$ \\
\hline $\mathrm{BK} 2$ & Kamper & 3.70 & 300 & 450 & Flexure \\
\hline
\end{tabular}

Table 4. Comparison Test Result in Fully composite and Ultimate Condition

\begin{tabular}{lllll}
\hline \multirow{2}{*}{$\begin{array}{l}\text { Beam } \\
\text { specimen }\end{array}$} & \multicolumn{2}{l}{ Fully composite condition } & Ultimate failure & \\
\cline { 2 - 5 } & Moment $(\mathrm{Nm})$ & Deflection, $\delta_{\mathrm{z}}(\mathrm{mm})$ & Moment $(\mathrm{Nm})$ & $\begin{array}{l}\text { Deflection, } \\
(\mathrm{mm})\end{array}$ \\
\hline AK1 & 63.30 & 0.37 & 660.44 & 32.18 \\
AK2 & 176.87 & 1.90 & 586.33 & 60.31 \\
BK1 & 195.90 & 2.08 & 988.91 & 37.62 \\
BK2 & 57.24 & 0.38 & 768.02 & 65.11 \\
\hline
\end{tabular}

Source: Research Documentation

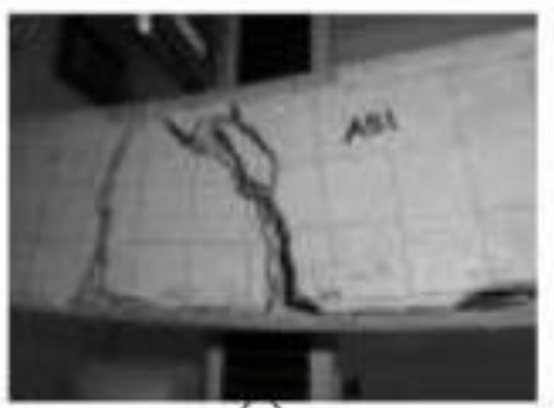

(a)

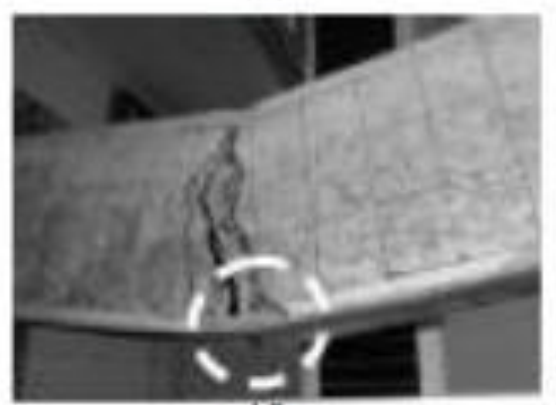

(d)

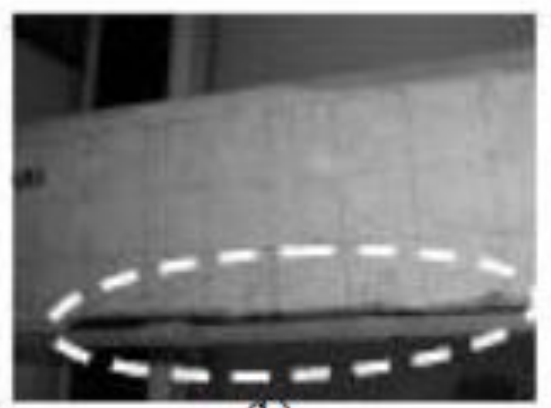

(b)

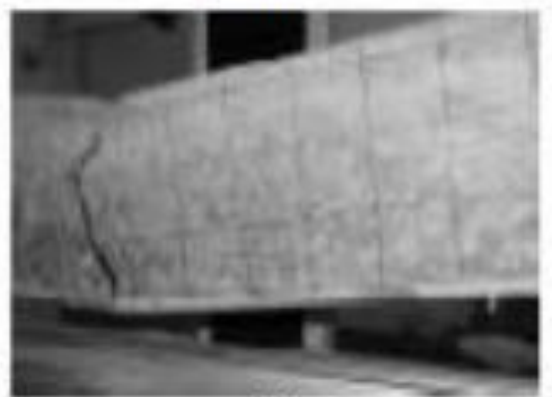

(e)

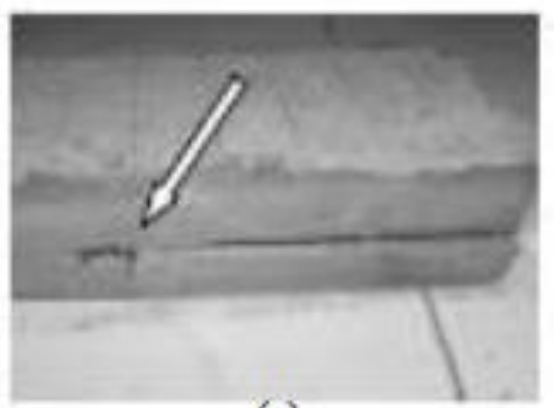

(c)

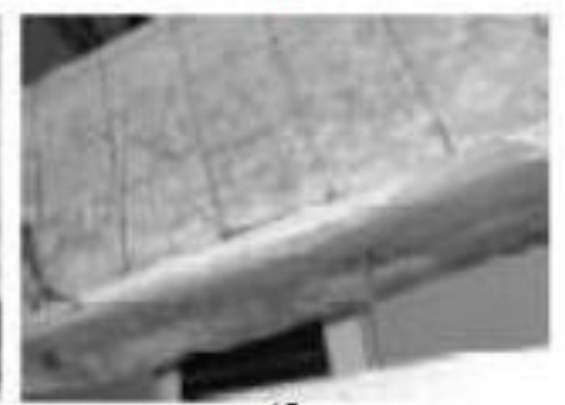

(f)

Hal. 113. Langkau Betang, Vol.2, No.2, 2015 


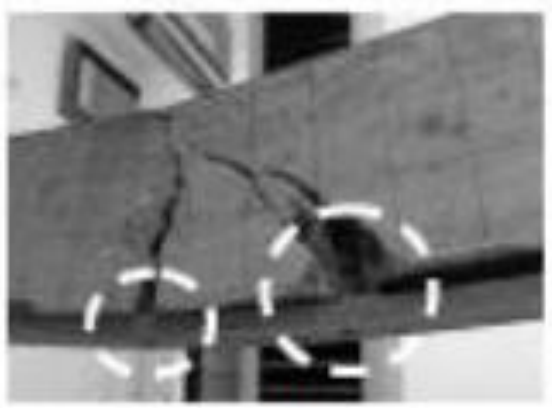

(g)

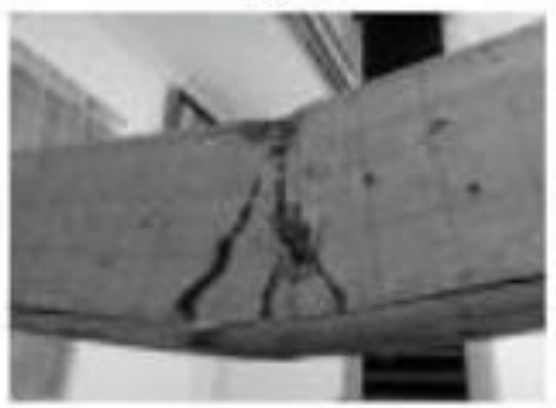

(j)

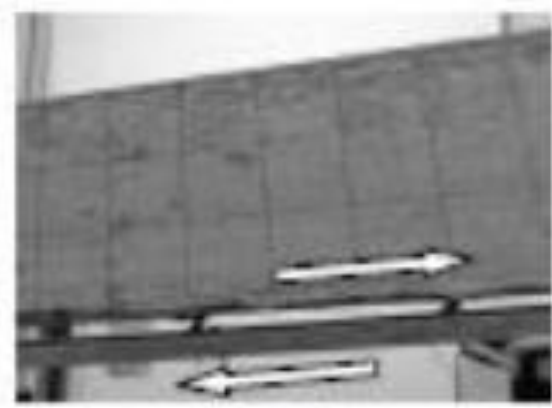

(h)

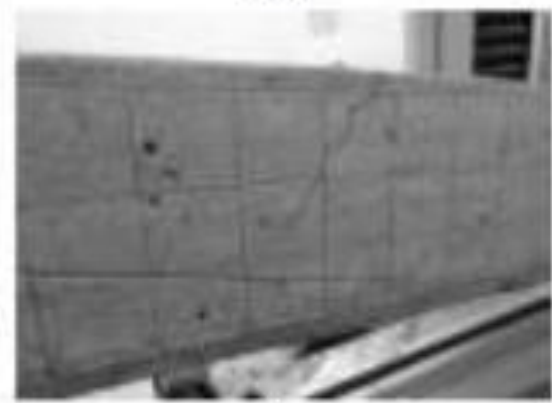

(k)

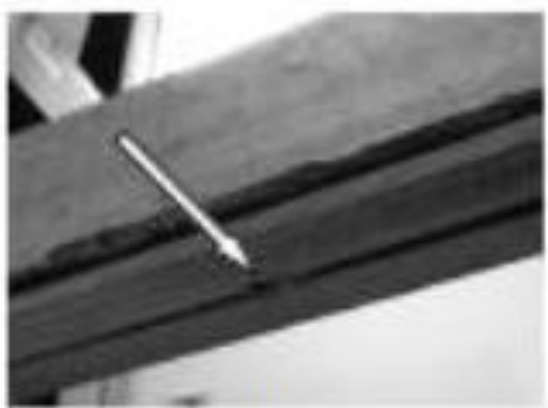

(i)

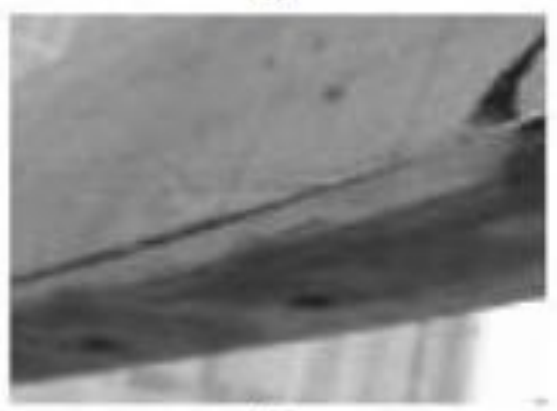

(I)

Figure 7. Beams Failure Modes

Source: Research Documentation

In Table 3 it can be seen that, for the same type of composite beams in ultimate condition, the capacity of composite beams with Bangkirai wood is always greater than the beams with Kamper wood. This is because of the contribution of the mechanical properties of those two kinds of wood especially bending strength (MOR) and modulus of elasticity (MOE). Bangkirai wood has MOR and MOE (124.3 Mpa dan $18700 \mathrm{MPa}$ ) that are greater than Kamper wood (89.98 MPa dan $13260 \mathrm{MPa})$ (Chauf 2005) even though both of these woods are classified as timber in strength class I-II (PKKI 1961) with a specific gravity of 0.62-0.9.

The composite beam using Bangkirai wood (BK1) has the largest ultimate load than other types of beams, namely $4.77 \mathrm{kN}$. This value is $28.92 \%$ greater than the same type beam $\left(\mathrm{CB}_{2}\right)$ that using different wood (BK2) and 50\% greater than the different type beam that using the same kind of wood (AK1). Meanwhile, the smallest ultimate load is owned by the composite beam with Kamper wood (AK2) namely $2.83 \mathrm{kN}$. This value is $40.67 \%$ smaller than BK1 and $11.01 \%$ smaller than the same type beam (AK1). But on the other hand BK2 is $30.74 \%$ greater than AK2. This indicates that the composite beam type $\mathrm{CB}_{2}$ is better than $\mathrm{CB}_{1}$ for both kinds of wood used.

On the other hand, in fully composite condition, the composite beam using Bangkirai wood type $\mathrm{CB}_{2}$ (BK1) also has the largest capacity compared to the other types of beams (Table 4). It can be seen from ultimate moment capacity of the available beams. Beam BK1 is able to withstand bending moments of $195.90 \mathrm{Nm}$. This value is three times larger than beam AK1 that is beam which using the same kind of wood but different in type. The smallest moment capacity is also owned by beam type $\mathrm{CB}_{2}$ but that using Kamper wood (BK2), namely 57.24 Nm, which is almost three a half time smaller than BK1.

\section{Conclusion}

Types of wood affect the strength of wood-concrete composite beams. The composite beam using Bangkirai wood as reinforcement is stronger than the beam using Kamper wood. Increasing in thickness of wood layer in tensile area will increase the bending capacity of the composite beams. Failure mode on composite beams tends to be same for same wood used. Identification to the beams 
conclude that the failure modes could be classified into flexural cracks, shear tension, and split on wood.

\section{References}

Boen T. (2010). Retrofitting Simple Buildings Damaged by Earthquakes. World Seismic Safety Initiative. Indonesia.

Chauf KA. (2005). Karakteristik Mekanik Kayu Kamper sebagai Bahan Konstruksi. Majalah Ilmiah MEKTEK 7: 41-47.

Gangarao HVS, Narendra T \& Vijay PV. (2007). Reinforced Concrete Design with FRP Composites. CRC Press, Boca Raton.

PKKI (Indonesian Timber Construction Code). (1961). PKKI NI - 5 1961. Direktorat Jenderal Cipta Karya Departemen Pekerjaan Umum, Bandung.

Pranata YA, Bambang S \& Johannes AT. (2012). Rasio Modulus Penampang Elastik Balok Kayu Laminasi-Baut. Jurnal Teknik Sipil 19: 223-236.

Thelandersson S. (2003). Introduction: Wood as a construction material. Pp 15-22 in Sven T \& Hans JL (Eds) Timber Engineering. John Wiley \& Sons Ltd, West Sussex. 